\title{
Familial infantile myoclonic epilepsy
}

INSERM

\section{Source}

INSERM. (1999). Orphanet: an online rare disease and orphan drug data base. Familial infantile myoclonic epilepsy. ORPHA:352582

A rare, genetic, infantile epilepsy syndrome disease characterized by neonatal- to infancyonset myoclonic focal seizures occurring in various members of a family, associated in some with mild dysarthria, ataxia and borderline-to-moderate intellectual disability. 